\title{
PENGARUH DEEP BACK MASSAGE TERHADAP INTENSITAS NYERI PERSALINAN KALA I FASE AKTIF DI RUANG BERSALIN RUMAH SAKIT IMMANUDIN KABUPATEN KOTAWARINGIN BARAT
}

\author{
${ }^{1}$ Jenny Oktarina ${ }^{2}$ Ayu asriana, ${ }^{3}$ Muniarti \\ STIKes Borneo Cendekia Medika Pangkalan Bun \\ ${ }^{1}$ Email: oktarina.jenny@yahoo.co.id ${ }^{2}$ ayu.asriana@gmail.com ${ }^{3}$ muniarti@gmail.com
}

\begin{abstract}
ABSTRAK
Persalinan merupakan proses menanti kelahiran yang akan dilalui seorang ibu dengan penuh rasa nyeri tetapi hal tersebut dapat teratasi dengan melakukan penekanan pada daerah sacrum secara mantap dengan telapak tangan, lepaskan dan tekan lagi atau disebut dengan deep back massage. Tujuan penelitian ini untuk menganalisis Pengaruh Deep Back Massage terhadap intensitas nyeri persalinan kala 1 fase aktif di Ruang Bersalin Rumah Sakit immanudin Kabupaten kotawaringin barat Tahun 2017. Desain penelitian adalah penelitian Pra Eksperiment dengan pendekatan metode One Group Pra-Post Test Design. Populasinya semua ibu bersalin pada saat penelitian, dengan sampel 21 responden diambil dengan tekhnik accidental sampling. Pengumpulan data dengan observasi.Dari hasil penelitian sebelum perlakuan hampir setengah responden mengalami nyeri berat terkontrol sebanyak 8 responden $(38,1 \%)$ dan setelah perlakuan hampir setengah responden mengalami nyeri sedang sebanyak 8 responden $(38,1 \%)$.Hasil analisa data menggunakan uji-T dengan nilai sig (2-tailed) : 0,000 dan $\square: 0,05$, jadi $<\square$ sehingga H0 ditolak dan $\mathrm{H} 1$ diterima, artinya ada perbedaan intensitas nyeri persalinan sebelum dan sesudah diberikan deep back massage. Diharapkan hasil penelitian ini dapat digunakan sebagai alternatif penurunan rasa nyeri pada persalinan dengan mudah dilakukan tanpa efek yang membahayakan dalam memberikan intervensi pada ibu selama persalinan kala I fase aktif.
\end{abstract}

\section{Kata kunci : Deep Back Massage, Nyeri Persalinan}

\section{THE EFFECT OF DEEP BACK MASSAGE ON THE INTENSITY OF LABOR PAIN IN ACTIVE PHASE IN THE IMMUNUDIN HOSPITAL SPACE}

\section{ABSTRACT}

Childbirth is a process of waiting for the birth that will be passed by a mother with great pain but it can be overcome by pressing the sacrum area firmly with the palm of the hand, release and press again or called a deep back massage. The purpose of this study was to analyze the Effect of Deep Back Massage on the intensity of first phase active labor pain in the delivery room of Immanudin Hospital, Kotawaringin Barat Regency in 2017. The study design was a Pre Experiment research with One Group Pre-Post Test Design method approach. The population was all women at the time of the study, with a sample of 21 respondents taken by accidental sampling 
technique. Data collection by observation. From the results of the study before treatment almost half of respondents experienced controlled severe pain as many as 8 respondents $(38.1 \%)$ and after treatment almost half of respondents experienced moderate pain as many as 8 respondents (38.1\%). - T with sig (2-tailed) values: 0,000 and $\square: 0.05$, so $<\square$ so that HO is rejected and H1 is accepted, meaning that there are differences in the intensity of labor pain before and after deep back massage. It is hoped that the results of this study can be used as an alternative to reducing pain in labor easily without any harmful effects in giving intervention to the mother during the first phase of labor during the active phase.

Keywords: Deep Back Massage, Labor Pain

\section{PENDAHULUAN}

Nyeri persalinan merupakan masalah yang sangat mencemaskan bagi ibu inpartu, khususnya ibu primigravida. Persalinan merupakan saat yang akan membahagiakan setiap keluarga tetapi proses menanti kelahiran ini akan dilalui seorang ibu dengan penuh rasa nyeri. Sebagian besar ibu yang melahirkan, merasakan nyeri saat persalinan itu dengan intensitas yang sangat berat, sehingga ibu-ibu tersebut menjadi sangat menderita, tegang, takut dan cemas, terutama pada wanita yang melahirkan pertama kali. Sebagian ibu menganggap nyeri itu tidak seberapa dan ada juga yang mengatakan sakitnya memang hebat. Kecemasan yang berlebihan tentang nyeri persalinan ini bisa berdampak buruk pada ibu maupun janin (www.suaramerdeka.com).

Ada berbagai metode untuk mengalihkan rasa nyeri pada saat persalinan biasanya yang paling sering dilakukan adalah metode massage, baik oleh petugas kesehatan, keluarga pasien maupun pasien itu sendiri. Namun kenyataannya metode massage yang dilakukan tidak pada tempatnya sehingga tidak efisien. Nyeri sulit didefinisikan karena nyeri merupakan sensasi yang bersifat sangat subyektif.
Contohnya pada pelaksanaan teknik Deep Back Massage, dimana seharusnya penekanan dilakukan tepat pada daerah sakrum dengan telapak tangan dan posisi ibu dalam keadaan berbaring miring tetapi kadang kala pelaksanaannya tidak sesuai sehingga nyeri yang dirasakan oleh pasien tidak dapat dialihkan. Hal ini mungkin diakibatkan oleh posisi ibu tidak dalam keadaan berbaring miring, atau penekanannya tidak tepat pada daerah sakrum. Selain itu alasan lain adalah untuk mengurangi penggunaan metode farmakologi yang menurut teori bahwa obat-obat tersebut memiliki efek samping yang membahayakan bagi ibu dan janin. Hal tersebut sesuai dengan penelitian yang dilakukan oleh Indah Lestari pada tahun 2010 dengan judul penelitian "Pengaruh Deep Back Massage Terhadap Penurunan Nyeri Persalinan Kala I Fase Aktif Dan Kecepatan Pembukaan Pada Ibu Bersalin Primigravida di BPS Wilayah Kerja Puskesmas Dlanggu Kabupaten Mojokerto" penelitian mengambil sampel sebanyak 34 responden dari penelitian tersebut menunjukkan bahwa ada pengaruh deep back massage terhadap penurunan nyeri persalinan kala I fase aktif dan kecepatan pembukaan pada ibu bersalin primigravida. Selain itu ada juga penelitian yang dilakukan oleh 
Desi Natalia pada tahun 2011 dengan judul "Pengaruh Pemberian Massage terhadap Pengurangan Intensitas Nyeri pada Persalinan Kala I Sebelum Dan Sesudah Intervensi di BPS Sukatmi Desa Grogol Kecamatan Grogol Kabupaten Kediri" penelitian mengambil sampel sebanyak 12 responden dari penelitian tersebut menunjukkan bahwa ada pengaruh pemberian massage terhadap pengurangan intensitas nyeri persalinan kala 1.

Berdasarkan studi pendahuluan yang dilakukan pada bulan agustus $2017 \mathrm{di}$ RSUD Sultan Imanuddin Kabupaten Kotawaringin Barat dengan melakukan observasi pada 10 ibu bersalin kala I fase aktif 8 ibu bersalin $(80 \%)$ mengalami nyeri, sedangkan pada 2 ibu bersalin (20\%) tidak mengalami nyeri persalinan. Diharapkan setelah dilakukan deep back massage, ibu bersalin mengalami penurunan nyeri persalinan sehingga ibu merasakan kenyamanan dan lebih rileks dalam mengalami proses persalinan.

Nyeri dan ketegangan emosional meningkatkan kadar kortisol dan katekolamin, yang dapat mempengaruhi lama dan intensitas persalinan. Rasa nyeri saat persalinan bisa meningkatkan tekanan darah, denyut jantung janin meningkat dan konsentrasi $\mathrm{ibu}$ selama persalinan menjadi terganggu. Semua itu akan berefek buruk terhadap kelancaran persalinan (Indriati, 2009). Penyebab terjadinya ketidaklancaran ataupun nyeri dapat terjadi dalam persalinan diantaranya faktor ibu, faktor lingkungan, kemampuan penolong. Faktor dari ibu diantaranya adalah power, passanger, passage, faktor lingkungan adalah suasana, keadaan lingkungan, faktor penolong adalah alat, cara menolong. Salah satu faktor yang perlu mendapatkan perhatian adalah faktor ibu yaitu tingkat kecemasan dalam menghadapi persalinan. Kecemasan dalam persalinan salah satunya juga dapat dipengaruhi oleh nyeri persalinan yang tidak terkoordinir dengan baik dan apabila tidak ditangani dengan baik akan dapat menimbulkan berbagai masalah baru dalam persalinan. Massage merupakan salah satu metode nonfarmakologi yang dilakukan untuk mengurangi rasa nyeri persalinan. Impuls rasa sakit yang dibawah oleh saraf yang berdiameter kecil menyebabkan gate control dispinal cord membuka dan impuls diteruskan ke korteks serebral sehingga akan menimbulkan rasa sakit. Tetapi impuls rasa sakit ini dapat diblok yaitu dengan memberikan rangsangan pada saraf yang berdiameter besar yang menyebabkan gate control akan tertutup dan rangsangan sakit tidak dapat diteruskan ke korteks serebral. Pada prinsipnya rangsangan berupa usapan pada saraf yang berdiameter besar yang banyak pada kulit harus dilakukan awal rasa sakit atau sebelum impuls rasa sakit yang dibawa oleh saraf yang berdiameter kecil mencapai korteks serebral.

Solusi dari masalah tersebut adalah penerapan berbagai metode untuk mengurangi nyeri persalinan baik secara farmakologi maupun nonfarmakologi. Manajemen nyeri secara farmakologi lebih efektif dibanding dengan metode nonfarmakologi, namun metode farmakologi lebih mahal, dan berpotensi mempunyai efek yang kurang baik. Sedangkan metode nonfarmakologi lebih murah, sederhana, efektif, dan tanpa efek yang 
merugikan. Menurut Mander (2008), metode ini dapat mencegah kesalahan yang berlebihan pasca-persalinan. Adapun metode non farmakoogis yang bisa digunakan untuk menurunkan intensitas nyeri saat persalinan adalah dengan metode deep back massage. Metode deep back massage dapat meningkatkan tingkat kenyamanan ibu dalam persalinan sehingga rasa nyeri yang ibu alami dapat berkurang dan persalinan dapat berjalan dengan lancar. Hal tersebut sesuai dengan penelitian yang dilakukan oleh Kusumawati pada tahun 2010 dengan judul "Efektifitas Massage Terhadap Nyeri Persalinan pada Ibu Primipara di BPS Wilayah Lowokwaru Malang" penelitian mengambil sampel sebanyak 30 responden, dari penelitian tersebut menyatakan bahwa pemberian massage lebih efektif terhadap nyeri persalinan dibandingkan dengan tanpa menggunakan message. Selain itu ada juga penelitian yang dilakukan oleh khoiruddin pada tahun 2012 dengan judul judul "Perbedaan Efektifitas Teknik Massage Menggunakan Counterpressure dengan Deep Back Massage terhadap Nyeri Persalinan Kala I Fase Aktif di RS Dr. Soetomo Malang" penelitian mengambil sampel sebanyak 20 responden, dari penelitian tersebut menunjukkan bahwa penggunaan teknik Deep Back Massage lebih efektif dibandingkan menggunakan teknik massage Counterpressure

Berdasarkan uraian diatas maka peneliti tertarik untuk melakukan penelitian tentang "Pengaruh Deep Back Massage terhadap Intensitas Nyeri Persalinan Kala 1 Fase Aktif di Ruang Bersalin RS. immanudin Kabupaten Kotawaringin Barat tahun 2017”.

\section{Konsep massage}

Dari hasil perdebatan tentang massage yang di lakukan oleh beberapa ahli, maka Haldeman dan Mobily mengombinasikan tentang pengertian massage "Massage adalah melakukan tekanan tangan pada jaringan lunak, biasanya otot, tendon atau legamentum, tanpa menyebabkan gerakan atau perubahan posisi sendi untuk meredakan nyeri, menghasilkan relaksasi, dan atau memperbaiki sirkulasi” (Mander, 2004).

Massage digunakan untuk membantu relaksasi dan menurunkan nyeri melalui peningkatan aliran darah pada daerah-daerah yang terpengaruh, merangsang reseptor-reseptor raba pada kulit sehingga merilekskan otototot, perubahan suhu kulit, dan secara umum memberikan perasaan nyaman yang berhubungan dengan keeratan hubungan manusia.

Massage dapat bermacam-macam bentuk mulai dari usapan ringan (belaian), sampai dengan massage mendalam pada kulit dan struktur dibawahnya. Menurut teori Gate Control Theory, hal ini diyakini bahwa dapat merangsang pengeluaran dari hormone endorphin, mengurangi produksi hormone catecholamine, dan merangsang hasil dari serabut syaraf afferent dalam memblokir transmisi rangsang nyeri.

Massage diberikan pada saat ibu inpartu merasa bahwa nyeri yang dirasakan sangat mengganggu dan menyiksa. Hal ini dikarenakan persepsi nyeri berbeda pada setiap individu. (Danuatmaja \& Meiliasari, 2004).

Indikasi pemberian Massage ibu inpartu dengan cara alamiah dan 
spontan atau tanpa induksi persalinan atau cara - cara lain yang berguna untuk mempercepat persalinan karena pada ibu yang dilakukan induksi persalinan atau cara - cara untuk menimbulakan medikasi nyeri karena Massage merupakan terapi nyeri yang paling sederhana (Danuatmaja \& Meiliasari, 2004).

\section{Konsep Nyeri Persalinan}

Nyeri telah didefinisikan oleh badan IASP (Internasional Association For The Pain) yaitu sensori subyektif dan emosional yang tidak menyenangkan yang didapat terkait dengan kerusakan jaringan aktual maupun potensial, atau menggambarkan kondisi terjadinya kerusakan (Yuliatun, 2008).

Nyeri persalinan berbeda dari nyeri pada umumnya, hal tersebut dapat dikarenakan nyeri persalinan merupakan bagian dari proses yang normal, sedangkan nyeri yang lain pada umumnya mengindikasikan adanya injuri atau penyakit, seorang ibu dapat mengetahui bahwa ia akan mengalami nyeri pada saat persalinan sehingga nyeri tersebut dapat diantisipasi, pengetahuan yang cukup tentang proses persalinan akan membantu seorang ibu untuk mengatasi nyeri persalinan yang bersifat intermittent (sementara), konsentrasi ibu yang tertuju pada bayi dapat menjadikan motivasi bagi ibu untuk lebih toleran terhadap rasa sakit yang dirasakan saat persalinan ( Yuliatun, 2008).

\section{Konsep Persalinan}

Persalinan adalah serangkaian kejadian yang berakhir dengan pengeluaran bayi cukup bulan atau hampir cukup bulan, disusul dengan pengeluaran plasenta dan selaput janin dari tubuh ibu (Yanti, 2010).

Ada sejumlah tanda-tanda dan gejala premonitor yang dapat memberitahukan anda terhadap wanita yang mendekati persalinan. Seorang wanita dapat menunjukkan beberapa,semua atau tidak sama sekali dari gejala-gejala tersebut, tetapi hal ini sangat berguna untuk diketahui ketika menemui wanita pada akhir kehamilan sehingga anda dapat memberikan petunjuk dan konseling antisipasi yang tepat (APN, 2004).

Menurut Ujiningtyas (2009), beberapa faktor yang berperan dalam persalinan antar lain :

1) Kekuatan Mendorong Jalan Keluar ( Power)

a) His (kontraksi uterus )

b) Kontraksi otot dinding perut

c) Kontraksi diafragma pelvis.

d) Ketegangan dan kontraksi ligamentum rotundum.

e) Efektivitas kekuatan pendorong.

f) Lama persalinan

2) Janin (Passanger)

a) Letak janin.

b) Posisi janin.

c) Presentasi janin.

d) Letak plasenta.

3) Jalan Lintas ( Passage)

a) Ukuran dan tipe panggul.

b) Kemampuan serviks untuk membuka.

c) Kemampuan kanalis vaginalis dan introitus vagina untuk memanjang.

4) Kejiwaan (Psyche)

a) Persiapan fisik untuk melahirkan.

b) Pengalaman persalinan.

c) Dukungan orang terdekat.

d) Intregitas emosional 
Mekanisme persalinan

Proses persalinan terdiri atas empat fase atau kala

Kala I : waktu mulai serviks membuka sampai pembukaan lengkap $10 \mathrm{~cm}$.

Kala II : waktu pengeluaran janin.

Kala III : waktu pelepasan plasenta dan pengeluaran plasenta.

Kala IV : waktu satu sampai dua jam setelah plasenta lahir. (Ujiningtyas, 2009)

\section{BAHAN DAN METODE PENELITIAN}

Jenis penelitian ini adalah survey analitik. Survey analitik, penelitian ini diarahkan untuk menjelaskan suatu keadaan atau situasi (Notoatmodjo, 2010).

Untuk menjawab rumusan masalah atau pertanyaan peneliti dan pencapaian tujuan penelitian, maka peneliti menggunakan desain penelitian Pra Eksperiment. Pra Eksperiment merupakan penelitian eksperiment yang paling lemah serta tidak untuk membuktikan kausal (Hidayat, 2010). Dengan pendekatan One Group Pra-Post Test Design, rancangan ini tidak ada kelompok pembanding (kontrol) tetapi paling tidak sudah dilakukan observasi pertama (pretest) yang memungkinkan peneliti dapat menguji perubahanperubahan yang terjadi setelah adanya eksperimen (program) (Notoatmodjo, 2010). Dalam penelitian ini, peneliti menggunakan desain penelitian pra eksperiment untuk mengetahui pengaruh Deep Back Massage terhadap intensitas nyeri persalinan kala 1 fase aktif di RS. immanudin Kabupaten Kotawaringin Barat tahun 2017.
Tabel 1.1 Tabel rancangan "One Group Pra-Post Test Design"

\begin{tabular}{|l|l|l|l|}
\hline Subjek & Pra & Perlakuan & Pasca \\
\hline K & O & I & O1 \\
& Waktu & Waktu 2 & Waktu \\
& 1 & & 3 \\
\hline
\end{tabular}

Keterangan :

$\mathrm{K}$ : Subjek (ibu bersalin)

$\mathrm{O}$ : Observasi nyeri persalinan sebelum pemberian Deep Back Massage

I : Intervensi (Deep Back Massage)

O1 : Observasi nyeri persalinan sesudah pemberian Deep Back Massage. (Nursalam, 2011)

\section{Tempat dan Waktu Penelitian}

1. Waktu penelitian

Penelitian ini dilaksanakan pada bulan Agustus 2017.

2. Tempat Penelitian Penelitian ini dilakukan di RS. immanudin Kabupaten Kotawaringin Barat tahun 2017.

Populasi dalam penelitian ini adalah semua ibu bersalin di RS. immanudin Kabupaten Kotawaringin Barat pada saat melakukan penelitian.

Sampel yang digunakan dalam penelitian ini adalah sebagian ibu bersalin di Ruang Bersalin RS. immanudin Kabupaten Kotawaringin Barat pada pada saat dilakukan penelitian yang memenuhi kriteria inklusi dan eksklusi sebagi berikut:

a. Kriteria Inklusi

Kriteria inklusi adalah karakter umum subjek penelitian dari suatu populasi target yang terjangkau yang akan diteliti (Nursalam, 2011).

Kriteria Inklusi dari penelitian ini adalah: 
1) Ibu inpartu kala I fase aktif dengan persalinan normal.

2) Ibu inpartu kala I fase aktif yang bersedia menjadi responden dan mendapat ijin dari keluarganya.

b. Kriteria eksklusi

Kriteria eksklusi adalah menghilangkan/mengeluarkan

subyek yang memenuhi kriteria eksklusi dari study (Nursalam, 2011).

Kriteria eksklusi dari penelitian ini adalah:

1) Ibu yang mengalami persalinan SC (Sectio Cesarea)

2) Ibu inpartu yang mendapatkan induksi persalinan.

Teknik yang digunakan dalam penelitian ini adalah Non Probability Sampling dengan metode Accidental Sampling. Pengambilan sampel secara aksidental (accidental) ini dilakukan dengan mengambil kasus atau responden yang kebetulan ada atau tersedia (Notoatmodjo, 2010).

Variabel independen dalam penelitian ini adalah deep back massage. Variabel dependen dalam penelitian ini adalah intensitas nyeri persalinan.

Pengumpulan data adalah suatu proses pendekatan kepada subyek dan proses pengumpulan karakteristik subyek yang diperlukan dalam penelitian.

\section{HASIL}

Hasil penelitian ini akan dibagi menjadi 2 bagian yaitu data umum dan data khusus. Data umum meliputi karakteristik responden yang meliputi umur responden, jenis persalinan, pendidikan, pekerjaan, pendamping persalinan, pola istirahat, pemenuhan gizi, informasi dan sumber informasi. Sedangkan data khusus meliputi pengaruh deep back massage terhadap intensitas nyeri persalinan kala 1 fase aktif.

1. Data Umum

\section{a. Karakteristik Responden Berdasarkan Umur}

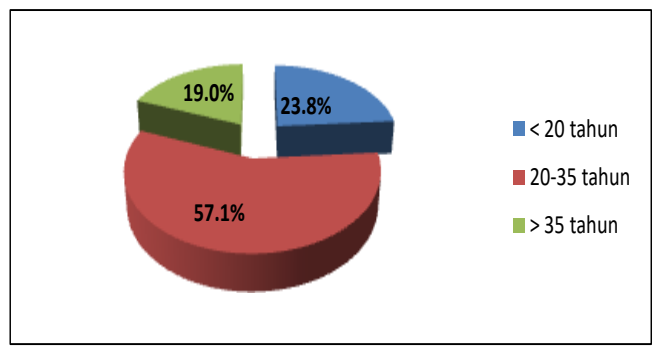

Diagram 1.1 Karakteristik Responden Berdasarkan Umur di Ruang Bersalin Rumah Sakit Immanudin Tahun 2017

Berdasarkan diagram 1.1 tersebut menunjukkan bahwa dari 21 responden sebagian besar berusia 20 35 tahun sebanyak 12 responden $(57,1 \%)$.

\section{b. Karakteristik Responden Berdasarkan Persalinan}

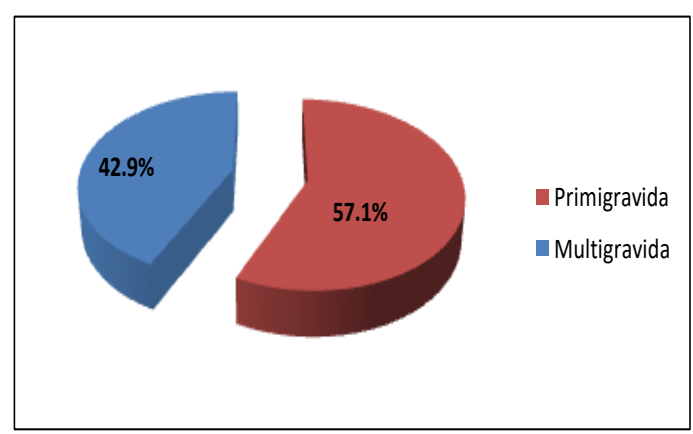

Diagram 1.2 Karakteristik Responden Berdasarkan Paritas di Ruang Bersalin Rumah Sakit Immanudin Tahun 2017 
Menurut diagram 1.2 tersebut menunjukkan bahwa dari 21 responden sebagian besar merupakan ibu primigravida yaitu sebanyak 12 responden $(57,1 \%)$.

\section{c. Karakteristik Responden Berdasarkan Pendidikan}

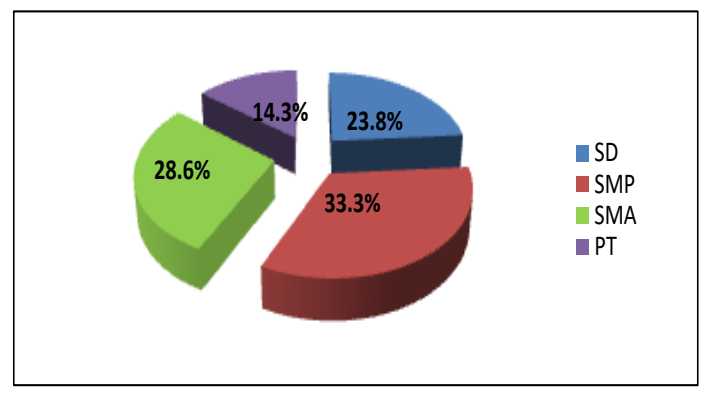

Diagram 1.3 Karakteristik Responden Berdasarkan Pendidikan di Ruang Bersalin Rumah Sakit Immanudin Tahun 2017

Diagram 1.3 tersebut menunjukkan bahwa dari 21 responden hampir setengahnya memiliki pendidikan SMP yaitu sebanyak 7 responden $(33,3 \%)$.

\section{d. Karakteristik Responden Berdasarkan Pekerjaan}

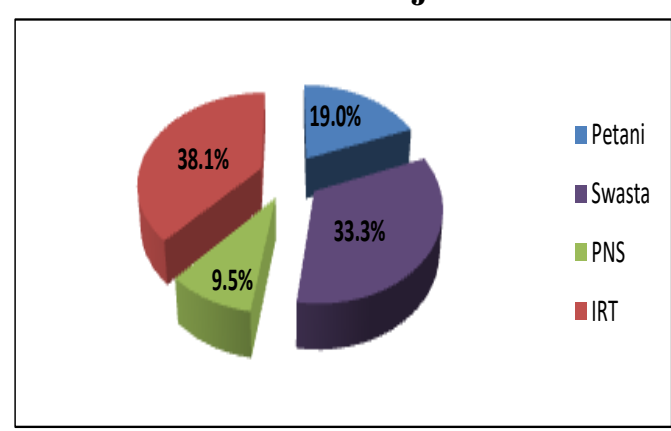

Diagram 1.4 Karakteristik Responden Berdasarkan Pekerjaan di Ruang Bersalin Rumah Sakit Immanudin Tahun 2017.

Diagram 1.4 tersebut menunjukkan bahwa dari 21 responden hampir setengahnya bekerja sebagai ibu rumah tangga sebanyak 8 responden $(38,1 \%)$.

\section{e. Karakteristik Responden Berdasarkan Pengalaman Mendapatkan Informasi}

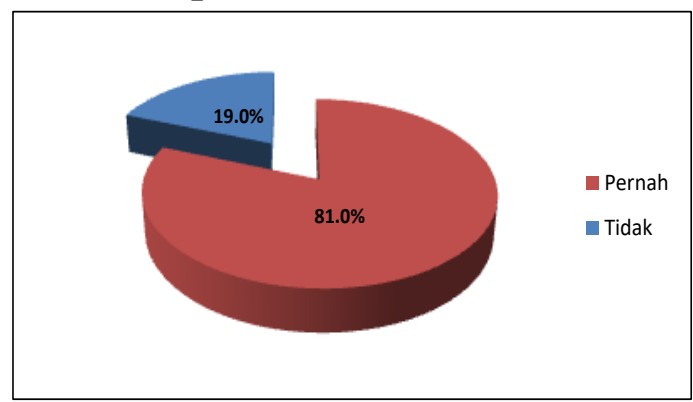

Diagram 1.5 Karakteristik Responden Berdasarkan Informasi di Ruang Bersalin Rumah Sakit Immanudin Tahun 2017

Dari diagram 1.5 tersebut menunjukkan bahwa dari 21 responden hampir seluruhnya pernah mendapatkan informasi yaitu sebanyak 17 responden $(81,0 \%)$.

\section{f. Karakteristik Responden Berdasarkan Sumber Informasi}

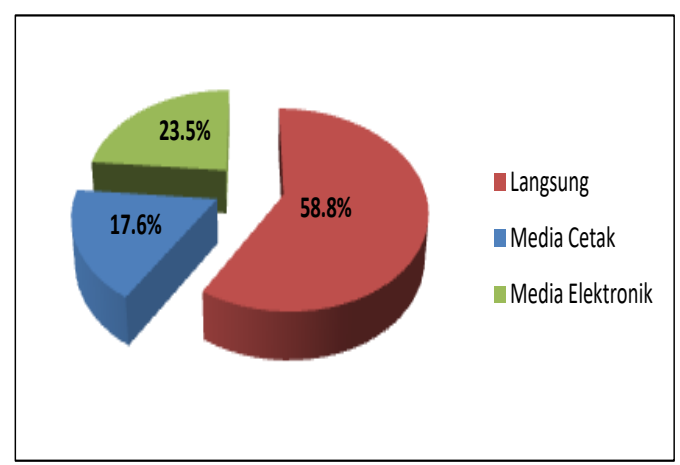

Diagram 1.6 Karakteristik

Responden Berdasarkan Sumber Informasi di Ruang Bersalin Rumah Sakit Immanudin Tahun 2017

Berdasarkan diagram 1.6 tersebut menunjukkan bahwa dari 17 responden yang pernah mendapatkan informasi sebagian besar mendapatkan 
informasi langsung dari petugas kesehatan yaitu sebanyak 10 responden $(58,8 \%)$.

\section{g. Karakteristik Berdasarkan Persalinan}

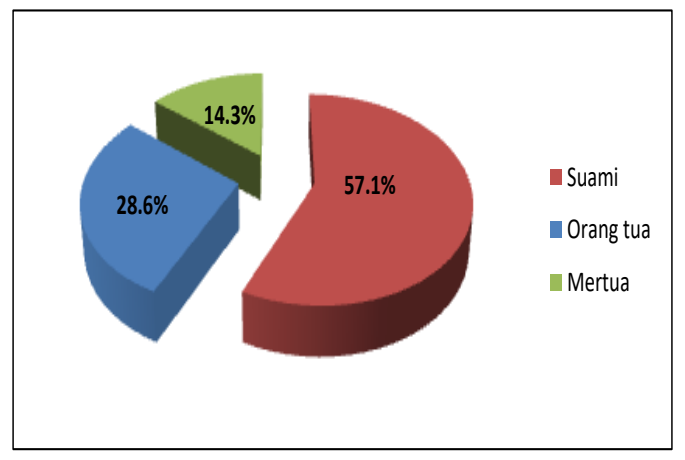

Diagram 1.7 Karakteristik Responden Berdasarkan Pendamping Persalinan di Ruang Bersalin Rumah Sakit Immanudin Tahun 2017

Menurut diagram 1.7 tersebut menunjukkan bahwa dari 21 responden sebagian besar saat persalinan didampingi oleh suami yaitu sebanyak 12 responden $(57,1 \%)$.

\section{h. Karakteristik Responden Berdasarkan Pola Istirahat}

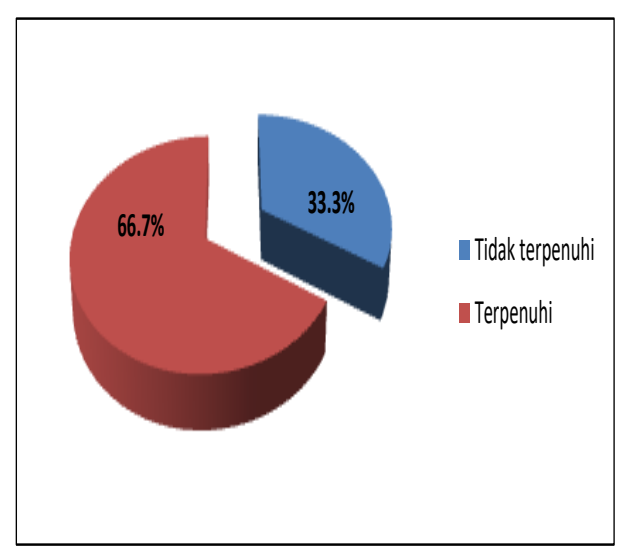

Diagram 1.8 Karakteristik

Responden Berdasarkan Pola Istirahat di Ruang Bersalin Rumah Sakit Immanudin Tahun 2017
Hasil dari diagram 1.8 tersebut menunjukkan bahwa dari 21 responden sebagian besar memiliki pola istirahat yang terpenuhi sebanyak 14 responden $(66,7 \%)$.

\section{i. Karakteristik Responden Berdasarkan Pemenuhan Gizi}

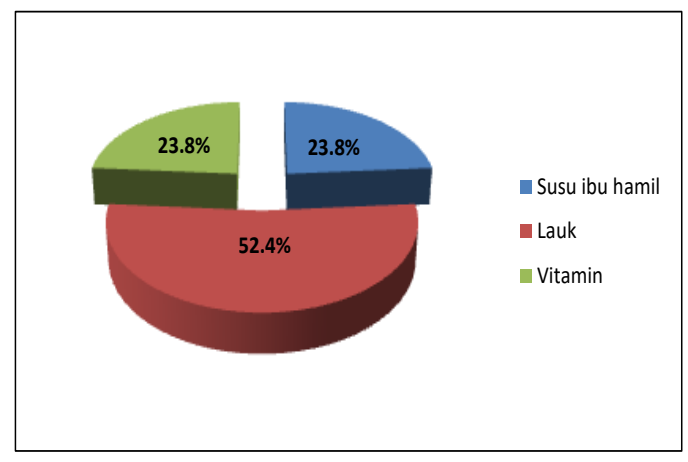

Diagram 1.9 Karakteristik Responden Berdasarkan Pemenuhan Gizi di Ruang Bersalin Rumah Sakit Immanudin Pangkalan bun Tahun 2017

Ditunjukkan pada diagram 1.9 tersebut menunjukkan bahwa dari 21 responden sebagian besar pemenuhan gizi dengan peningkatan lauk setiap hari sebanyak 11 responden $(52,4 \%)$.

\section{Data Khusus}

Pada data khusus akan ditampilkan krakterisitik responden berdasarkan intensitas nyeri sebelum dilakukan perlakuan, intensitas nyeri setelah dilakukan perlakuan, dan pengaruh deep back massage terhadap intensitas nyeri persalinan kala 1 fase aktif.

a. Intensitas nyeri persalinan sebelum perlakuan

Intensitas nyeri persalinan sebelum diberi perlakuan deep back massage di ruang bersalin Rumah Sakit Immanudin Pangkalan bun Tahun 
2017 dapat dilihat pada tabel berikut ini :

Tabel 1.1 Karakteristik Responden Berdasarkan Intensitas Nyeri Persalinan Sebelum Perlakuan di Ruang Bersalin Rumah Sakit Immanudin Pangkalan bun Tahun 2017

\begin{tabular}{|c|l|c|c|}
\hline No. & $\begin{array}{l}\text { Tingkatan } \\
\text { Nyeri }\end{array}$ & Jumlah & Prosentase \\
\hline 1. & Tidak Nyeri & 0 & $0,0 \%$ \\
\hline 2. & Nyeri Ringan & 0 & $0,0 \%$ \\
\hline 3. & $\begin{array}{l}\text { Nyeri } \\
\text { Sedang }\end{array}$ & 6 & $28,6 \%$ \\
\hline 4. & $\begin{array}{l}\text { Nyeri Berat } \\
\text { Terkontrol }\end{array}$ & 8 & $38,1 \%$ \\
\hline 5. & $\begin{array}{l}\text { Nyeri Berat } \\
\text { Tidak } \\
\text { Terkontrol }\end{array}$ & 7 & $33,3 \%$ \\
\hline \multicolumn{2}{|l}{ JMLAH } & 21 & $100 \%$ \\
\hline
\end{tabular}

Berdasarkan tabel 1.1 dapat diketahui bahwa sebelum perlakuan dari 21 responden hampir setengahnya mengalami nyeri berat terkontrol sebanyak 8 responden $(38,1 \%)$, hampir setengahnya mengalami nyeri berat tidak terkontrol sebanyak 7 responden $(33,3 \%)$, sebagian kecil mengalami nyeri sedang sebanyak 6 responden $(28,6 \%)$ dan sementara itu tidak ada responden yang tidak mengalami nyeri maupun nyeri ringan.

b. Intensitas nyeri persalinan setelah perlakuan

Intensitas nyeri persalinan setelah diberi perlakuan deep back massage di ruang bersalin Rumah Sakit Immanudin Kabupaten Kotawaringin Barat Tahun 2017 dapat dilihat pada tabel berikut ini :

Tabel 1.2 Karakteristik Responden Berdasarkan Intensitas Nyeri Persalinan Setelah Perlakuan di Ruang Bersalin Rumah Sakit
Immanudin

Kabupaten

Kotawaringin Barat Tahun 2017

\begin{tabular}{|c|l|c|c|}
\hline No. & $\begin{array}{l}\text { Tingkatan } \\
\text { Nyeri }\end{array}$ & Jumlah & Prosentase \\
\hline 1. & $\begin{array}{l}\text { Tidak } \\
\text { Nyeri }\end{array}$ & 0 & $0,0 \%$ \\
\hline 2. & $\begin{array}{l}\text { Nyeri } \\
\text { Ringan }\end{array}$ & 6 & $28,6 \%$ \\
\hline 3. & $\begin{array}{l}\text { Nyeri } \\
\text { Sedang }\end{array}$ & 8 & $38,1 \%$ \\
\hline 4. & $\begin{array}{l}\text { Nyeri } \\
\text { Berat } \\
\text { Terkontrol }\end{array}$ & 4 & $19,0 \%$ \\
\hline 5. & $\begin{array}{l}\text { Nyeri } \\
\text { Berat } \\
\text { Tidak } \\
\text { Terkontrol }\end{array}$ & 21 & 100 \\
\hline \multicolumn{2}{|c|}{ JUMLAH } \\
\hline
\end{tabular}

Berdasarkan tabel 1.2 dapat diketahui bahwa setelah perlakuan dari 21 responden hampir setengahnya mengalami nyeri sedang sebanyak 8 responden $(38,1 \%)$, hampir setengahnya mengalami nyeri ringan yaitu sebanyak 6 responden $(28,6 \%)$, sebagian kecil mengalami nyeri berat terkontrol sebanyak 4 responden $(19,0 \%)$, sebagian kecil mengalami nyeri berat tidak terkontrol sebanyak 3 responden $(14,3 \%)$ dan sementara itu tidak ada responden yang tidak mengalami nyeri.
c. Pengaruh Deep Back Massage terhadap Intensitas Nyeri Persalinan Kala 1 Fase Aktif

Pengaruh deep back massage terhadap intensitas nyeri persalinan kala 1 fase aktif di ruang bersalin Rumah Sakit

\begin{tabular}{|l|c|c|c|}
\hline Variabel & Sampel & $\begin{array}{c}\text { Nilai } \\
\text { Hasil } \\
\text { Uji T }\end{array}$ & $\begin{array}{c}\text { Nilai } \\
\text { Signifikan } \\
(\rho)\end{array}$ \\
\hline $\begin{array}{l}\text { Skor nyeri } \\
\text { persalinan } \\
\text { pre deep } \\
\text { back } \\
\text { massage \& } \\
\text { skor nyeri } \\
\text { persalinan } \\
\text { post deep } \\
\text { back } \\
\text { massage }\end{array}$ & 21 & .929 & .000 \\
\hline
\end{tabular}


Immanudin Kabupaten Kotawaringin Barat Tahun 2017 dapat dilihat pada tabel berikut ini :

Tabel 1.3 Pengaruh Deep Back Massage terhadap Intensitas Nyeri Persalinan Kala 1 Fase Aktif di Ruang Bersalin Rumah Sakit Immanudin Kabupaten Kotawaringin Barat Tahun 2017

\begin{tabular}{|c|c|c|c|c|c|c|c|c|c|c|c|c|}
\hline \multirow{2}{*}{$\begin{array}{l}\text { Skala } \\
\text { Nyeri } \\
\text { Kelomp } \\
\text { ok } \\
\text { Respon } \\
\text { den }\end{array}$} & \multicolumn{2}{|c|}{$\begin{array}{l}\text { Tidak } \\
\text { Nyeri }\end{array}$} & \multicolumn{2}{|c|}{$\begin{array}{c}\text { Nyeri } \\
\text { Ringa } \\
\text { n }\end{array}$} & \multicolumn{2}{|c|}{$\begin{array}{c}\text { Nyeri } \\
\text { Seda } \\
\text { ng }\end{array}$} & \multicolumn{2}{|c|}{\begin{tabular}{|c|} 
Nyeri \\
Berat \\
Terkont \\
rol
\end{tabular}} & \multicolumn{2}{|c|}{$\begin{array}{c}\text { Nyeri } \\
\text { Berat } \\
\text { Tidak } \\
\text { Terkon } \\
\text { trol } \\
\end{array}$} & \multicolumn{2}{|c|}{ Total } \\
\hline & $\Sigma$ & $\%$ & $\sum$ & $\%$ & $\sum$ & $\%$ & $\sum$ & $\%$ & $\sum$ & $\%$ & $\sum$ & $\%$ \\
\hline $\begin{array}{c}\text { Sebelum } \\
\text { Perlakua } \\
\mathrm{n}\end{array}$ & 0 & 0,0 & 0 & 0,0 & 6 & 28,6 & 8 & $\begin{array}{c}3 \\
8, \\
1\end{array}$ & 7 & $\begin{array}{l}3 \\
3, \\
3\end{array}$ & 21 & $\begin{array}{c}100, \\
0\end{array}$ \\
\hline $\begin{array}{c}\text { Sesudah } \\
\text { Perlakua } \\
\text { n }\end{array}$ & 0 & 0,0 & 6 & $\begin{array}{c}28, \\
6\end{array}$ & 8 & 38,1 & 4 & 19,0 & 3 & $\begin{array}{l}1 \\
4, \\
3\end{array}$ & 21 & $\begin{array}{c}100, \\
0\end{array}$ \\
\hline
\end{tabular}

Berdasarkan tabel 1.3 dapat diketahui bahwa sebelum perlakuan dari 21 responden hampir setengahnya mengalami nyeri berat terkontrol sebanyak 8 responden $(38,1 \%)$, nyeri berat tidak terkontrol sebanyak 7 responden $(33,3 \%)$, dan nyeri sedang sebanyak 6 responden $(28,6 \%)$ dan tidak ada responden yang tidak mengalami nyeri maupun nyeri ringan. Sesudah perlakuan dari 21 responden hampir setengahnya mengalami nyeri sedang sebanyak 8 responden $(38,1 \%)$, nyeri ringan sebanyak 6 responden $(28,6 \%)$, nyeri berat terkontrol 4 responden $(19,0 \%)$, nyeri berat tidak terkontrol 3 responden $(14,3 \%)$ dan tidak ada responden yang tidak mengalami nyeri.

\section{Analisa Data}

Dengan menggunakan rumus $U j i T$ test yang dihitung dengan SPSS telah didapatkan hasil sebagai berikut :

Tabel 1.4 Hasil Uji Paired Samples Correlations Pengaruh Deep Back
Massage terhadap Intensitas Nyeri Persalinan Kala 1 Fase Aktif di Ruang Bersalin Rumah Sakit Immanudin Kabupaten Kotawaringin Barat Tahun 2017

Berdasarkan tabel 1.4 diketahui ada pengaruh pemberian deep back massage terhadap intensitas Nyeri Persalinan Kala 1 fase aktif di di Ruang Bersalin Rumah Sakit Immanudin Kabupaten Kotawaringin Barat Tahun 2017. Analisa data menggunakan uji-T pada intensitas nyeri persalinan sebelun dan sesudah diberikan perlakuan didapatkan hasil nilai sig (2-tailed) $\rho: 0,000$ dan $\alpha$ : 0,05 , jadi $\rho<\alpha$ sehingga $\mathrm{H}_{0}$ ditolak dan $\mathrm{H}_{1}$ diterima, artinya ada perbedaan intensitas nyeri persalinan sebelum dan sesudah diberikan deep back massage.

\section{PEMBAHASAN}

Pembahasan dilakukan pada masingmasing variabel yaitu tentang intensitas nyeri persalinan sebelum dilakukan deep back massage, intensitas nyeri persaliann sesudah dilakukan deep back massage, selanjutnya analisis pengaruh deep back massage terhadap intensitas nyeri persalinan kala 1 fase aktif.

\section{Intensitas Nyeri Persalinan Sebelum Dilakukan Deep Back Massage}

Berdasarkan hasil penelitian diketahui bahwa sebelum perlakuan dari 21 responden hampir setengahnya mengalami nyeri berat terkontrol sebanyak 8 responden $(38,1 \%)$.

Rasa nyeri pada persalinan kala I terjadi karena aktivitas besar di dalam tubuh guna mengeluarkan bayi. Persalinan diartikan sebagai 
peregangan pelebaran mulut rahim. Kejadian itu terjadi ketika otot-otot rahim berkontraksi untuk mendorong bayi keluar. Otot-otot rahim menegang selama kontraksi. Bersamaan dengan setiap kontraksi, kandung kemih, rektum, tulang belakang, dan tulang pubic menerima tekanan kuat dari rahim. Berat dari kepala bayi ketika bergerak ke bawah saluran lahir juga menyebabkan tekanan. Rasa sakit kontraksi dimulai dari bagian bawah punggung, kemudian menyebar ke bagian bawah perut mugkin juga menyebar ke kaki. Rasa sakit dimulai seperti sedikit tertusuk, lalu mencapai puncak, kemudian menghilang seluruhnya (Danuatmadja, 2007).

Rasa nyeri persalinan bersifat personal, setiap orang mempersepsikan rasa nyeri yang berbeda terhadap stimulus yang sama tergantung pada ambang nyeri yang dimilikinya. Pada dasarnya serviks pada ibu multipara mengalami perlunakan sebelum persalinan, tidak demikian halnya dengan serviks pada ibu primipara yang menyebabkan nyeri pada primipara lebih berat daripada multipara (Yuliatun , 2008).

Nyeri yang dirasakan ibu merupakan akibat respon psikis dan reflek fisik. Perbedaan persepsi nyeri yang dirasakan oleh primipara dapat terjadi, hal ini dikarenakan oleh adanya perbedaan kemampuan setiap ibu dalam merespon dan mempersepsikan nyeri yang dialaminya. Kemampuan merespon dan mempersepsikan nyeri dipengaruhi oleh banyak faktor, diantaranya adalah faktor usia, mekanisme koping dan tingkat pengetahuan. Ibu dengan usia muda mengalami nyeri persalinan tidak seberat dan selama primipara dengan usia yang lebih tua. Disamping itu, tingkat pengetahuan yang dimiliki ibu berbeda pada tiap individunya sehingga antar ibu bersalin memiliki koping yang berbeda dalam mengontrol nyeri. Pemilihan koping yang positif akan dapat mengontrol nyeri lebih efektif.

Beberapa faktor yang mempengaruhi nyeri persalinan menurut Tamsuri (2007) antara lain: umur, paritas, ras, budaya, etnik, mekanisme koping, metode relaksasi yang digunakan, cemas atau takut, kelelahan, lama persalinan dan posisi maternal atau fetal.

Karakteristik responden berdasarkan umur menunjukkan bahwa dari 21 responden sebagian besar berusia 20 35 tahun sebanyak 12 responden $(57,1 \%)$.

Wanita dengan usia muda mengalami nyeri tidak seberat nyeri yang di rasakan pada wanita dengan usia yang lebih tua (Tamsuri, 2007). Dari segi kepercayaan masyarakat seseorang yang lebih dewasa akan lebih di percayai dari orang yang belum cukup tinggi kedewasaanya. Hal ini sebagai akibat dari pengalaman dan kematangan jiwanya (Nursalam, 2008).

Menurut peneliti umur responden ini termasuk dewasa, sehingga sudah banyak pengalaman berkaitan dengan persalinan. Sesuai dengan teori yang ada dijelaskan bahwa nyeri persalinan juga dapat dipengaruhi oleh faktor pengalaman. Melalui pengalaman yang didapat maka seseorang dapat mengambil kesimpulan. Kesimpulan ini pada akhirnya menjadi sumber pengetahuan baru bagi seseorang. Sama dengan hasil penelitian ini mengingat pentingnya mengurangi 
nyeri persalinan yang dihadapi oleh ibu yang akan melahirkan.

Karakteristik responden berdasarkan paritas menunjukkan bahwa dari 21 responden sebagian besar merupakan ibu primigravida yaitu sebanyak 12 responden $(57,1 \%)$.

Serviks pada wanita multipara mengalami perlunakan sebelum onset persalinan, namun tidak demikian halnya dengan serviks pada wanita primipara yang menyebabkan nyeri pada primipara lebih berat daripada multipara (Tamsuri, 2007). Wanita dengan usia muda mengalami nyeri tidak seberat nyeri yang di rasakan pada wanita dengan usia yang lebih tua (Yuliatun, 2008).

Menurut pendapat peneliti bahwa tingkatan nyeri dipengaruhi oleh berbagai hal diantaranya faktor fisik yang terdiri dari intensitas dan lamanya kontraksi rahim, besarnya janin, keadaan umum ibu, pembukaan mulut rahim. Pada faktor psikologik reaksi pasien terhadap rasa nyeri pada persalinan berbeda - beda. Hal ini antara lain tergantung dari sikap dan keadaan mental pasien, kebiasaan, dan budaya. Dari beberapa faktor tersebut bisa mengurangi atau bahkan meningkatkan derajat nyeri persalinan yang dirasakan. Seseorang wanita yang belum pernah mengalami persalinan akan mengalami nyeri persalinan yang lebih hebat dibandingkan dengan wanita yang sudah pernah melahirkan hal ini disebabkan oleh serviks pada wanita multipara mengalami perlunakan.

\section{Intensitas Nyeri Persalinan Setelah Dilakukan Deep Back Massage}

Berdasarkan hasil penelitian diketahui bahwa setelah perlakuan dari 21 responden hampir setengahnya mengalami nyeri sedang sebanyak 8 responden $(38,1 \%)$.

Massage merupakan metode yang digunakan secara umum dalam persalinan untuk membantu mengurangi nyeri (Yanti, 2010). Bidan mempunyai andil yang sangat besar dalam mengurangi nyeri persalinan secara nonfarmakologi. Salah satu cara bidan yang bisa dilakukan untuk menguragi nyeri persalinan secara nonfarmakologi adalah dengan massage.

Tindakan penekanan oleh tangan pada jaringan lunak, biasanya otot tendon atau ligamen, tanpa menyebabkan pergeseran atau perubahan posisi sendi guna menurunkan nyeri, menghasilkan relaksasi, dan atau meningkatkan sirkulasi (Luluvikar, 2009). Menurut Gate control theory mengurangi nyeri persalinan dengan massage diyakini bahwa dapat merangsang pengeluaran dari hormon endhorpin, mengurangi produksi hormon catecholamin, dan merangsang hasil dari serabut syaraf afferent dalam memblokir transmisi rangsang nyeri (Yanti, 2010)

Penurunan lama nyeri kontraksi kala I fase aktif terjadi karena deep back massage memberikan efek distraksi dan relaksasi. Selain itu, penekanan di daerah sakrum pada aplikasi dari teknik deep back massage ini merupakan tindakan yang dapat memblok transmisi impuls nyeri dari sumber nyeri yang bersal dari serviks dan corpus uteri sehingga intensitas nyeri persalinan dapat turun lebih cepat. 
Menurut pendapat peneliti banyak cara yang dilakukan untuk menurunkan nyeri pada persalinan, baik secara farmakologi maupun nonfarmakologi. Manajemen nyeri secara farmakologi lebih efektif dibanding dengan metode nonfarmakologi, namun metode farmakologi lebih mahal, dan berpotensi mempunyai efek yang kurang baik untuk ibu dan janin. Sedangkan metode nonfarmakologi lebih murah, efektif dan tanpa efek yang merugikan. Metode pengurangan nyeri yang sering digunakan adalah massage, selain mudah penatalaksanaannya juga karena massage diyakini oleh banyak ibu bersalin dapat mengurangi nyeri persaliannya. Pemberian massage tersebut bisa dilakukan oleh petugas kesehatan, keluarga pasien, maupun pasien itu sendiri. Sumber nyeri yang sering dijumpai adalah didaerah pinggang, perut dan sacrum ibu. Massage yang benar dan tepat tidak dilakukan sekali saja tetapi berulangulang kali kurang lebih 20 menit setiap jam. Pada waktu penelitian kebanyakan ibu mengatakan merasakan nyerinya berkurang sesudah diberikan deep back massage dan ibu merasa nyaman saat diberikan massage pada daerah sumber nyeri tersebut.

\section{Pengaruh Deep Back Massage terhadap Intensitas Nyeri Persalinan Kala I Fase Aktif}

Berdasarkan hasil penelitian diketahui bahwa sebelum perlakuan dari 21 responden hampir setengahnya mengalami nyeri berat terkontrol sebanyak 8 responden $(38,1 \%)$, nyeri berat tidak terkontrol sebanyak 7 responden $(33,3 \%)$, dan nyeri sedang sebanyak 6 responden $(28,6 \%)$ dan tidak ada responden yang tidak mengalami nyeri maupun nyeri ringan. Sesudah perlakuan dari 21 responden hampir setengahnya mengalami nyeri sedang sebanyak 8 responden $(38,1 \%)$, nyeri ringan sebanyak 6 responden $(28,6 \%)$, nyeri berat terkontrol 4 responden $(19,0 \%)$, nyeri berat tidak terkontrol 3 responden $(14,3 \%)$ dan tidak ada responden yang tidak mengalami nyeri.

Hasil uji statistik Paired $T$ - test dengan menggunakan program SPSS diketahui nilai koefisien $\mathrm{P}=0,000$, berarti $\mathrm{P}<\alpha$ yang bermakna ada pengaruh deep back massage terhadap intensitas nyeri persalinan kala 1 fase aktif.

Pemberian massage dapat membantu ibu merasa lebih segar, nyaman dan rileks selama persalinan. Sebuah penelitian menyebutkan bahwa ibu yang diberikan selama kurang lebih 20 menit setiap jam selama tahapan persalinan akan lebih bebas dari rasa sakit. Hal ini disebabkan karena massage merangsang tubuh untuk melepaskan senyawa endhorpin yang merupakan pereda sakit alami. Endhorpin juga dapat menciptakan perasaan nyaman dan enak (Danuatmadja, 2007).

Menurut pendapat peneliti pemberian massage ini sangat bagus digunakan untuk ibu bersalin untuk mengurangi nyeri persalinan karena massage adalah salah satu cara pengurangan nyeri persalinan secara nonfarmakologi yang tidak membahayakan. Ibu yang diberikan massage sebagian besar mengatakan nyeri ibu sedikit berkurang dan ibu merasakan nyaman saat diberikan massage. Dengan demikian deep back massage mempunyai pengaruh terhadap pengurangan intensitas nyeri 
persalinan kala 1 yang dibuktikan dengan adanya perubahan intensitas nyeri pada ibu bersalin.

Meskipun demikian, masih terdapat responden yang merasakan nyeri kontraksi dalam waktu yang lama sesudah dilakukan deep back massage bahkan mengalami peningkatan. Hal ini dikarenakan adanya perbedaan ambang nyeri pada masing-masing responden. Responden yang mempunyai ambang nyeri yang tinggi tidak akan mengeluh nyeri dengan stimulus kecil, sebaliknya responden dengan ambang nyeri rendah akan mudah merasa nyeri dengan stimulus nyeri kecil. Pada saat peneliti melakukan penelitian terdapat pasien yang masuk ruang bersalin sudah merasakan nyeri berat tidak terkontrol setelah diberikan perlakuan pasien semakin menjerit dan berteriak-teriak, tetapi ada juga responden yang merasakan nyeri berat terkontrol setelah diberikan perlakuan pasien merasa lebih nyaman dan nyeri yang dirasakan semakin berkurang serta proses persalinan dapat berjalan dengan lancar tanpa ada komplikasi serta bayi lahir dengan selamat.

\section{SIMPULAN DAN SARAN}

\section{Simpulan}

Berdasarkan penyajian data dan hasil analisis data tentang pengaruh deep back massage terhadap intensitas nyeri persalinan kala 1 fase aktif di Ruang Bersalin Rumah Sakit Immanudin Kabupaten Kotawaringin Barat Tahun 2017 maka dapat disimpulkan sebagai berikut :

1. Intensitas nyeri persalinan sebelum perlakuan hampir setengah dari responden mengalami nyeri berat terkontrol sebanyak 8 responden atau $38,1 \%$ dari jumlah seluruh responden.

2. Intensitas nyeri persalinan sesudah perlakuan hampir setengah dari responden mengalami nyeri sedang sebanyak 8 responden atau $38,1 \%$ dari jumlah seluruh responden.

3. Hasil Analisa data menggunakan uji-T pada intensitas nyeri persalinan sebelun dan sesudah diberikan perlakuan didapatkan hasil nilai sig (2-tailed) $\rho: 0,000$ dan $\alpha: 0,05$, jadi $\rho<\alpha$ sehingga $\mathrm{H}_{0}$ ditolak dan $\mathrm{H}_{1}$ diterima, artinya ada perbedaan intensitas nyeri persalinan sebelum dan sesudah diberikan deep back massage.

\section{Saran}

\section{Bagi Subyek Penelitian}

Hasil penelitian ini dapat digunakan sebagai alternatif penurunan rasa nyeri pada persalinan dengan mudah dilakukan tanpa efek yang membahayakan dalam memberikan intervensi pada ibu selama persalinan kala I fase aktif, sehingga diharapkan keluarga dapat mempraktekkan depp back massage selama proses persalinan agar intensitas nyeri ibu dapat berkurang sehingga memperlancar proses persalinan.

\section{Bagi Obyek Penelitian}

Hasil penelitian ini semoga dapat memberikan manfaat sebagai masukan, memberikan informasi tentang pengaruh teknik deep back massage terhadap respon adaptasi nyeri pada pasien inpartu kala I dan diharapkan dapat mengelola, melayani pasien yang sedang mengalami proses persalinan dalam hal massage yang tepat dan benar, sehingga pasien dapat 
menjalani proses persalinan dengan baik dan terkontrol.

\section{Bagi Peneliti Selanjutnya}

Semoga hasil penelitian ini dapat memberikan manfaat sebagai acuan peneliti selanjutnya dan menambah variabel akan penelitian selanjutnya tentang pengaruh teknik Deep Back Massage terhadap respon adaptasi nyeri pasien beserta keluarganya saat persalinan inpartu kala I fase aktif.

\section{DAFTAR PUSTAKA}

Arikunto. 2006. Prosedur Penelitian Suatu Pendekatan Praktik. Jakarta: Rineka Cipta.

Bobak. 2004. Keperawatan Maternitas. Jakarta : EGC.

Danuatmaja. 2004. Persalinan Normal Tanpa Rasa Sakit. Jakarta : Puspa Swara.

Fatimah. 2013. Angka Kejadian Nyeri Persalinan. http://www.fatimahblog spot. co.id. Diakses tanggal 22 Januari 2014.

Handerson. 2005. Buku Ajar Konsep

Kebidanan (Essential Midwifery). Jakarta : EGC.

Hidayat. 2010. Metode Penelitian Kebidanan \& Tehnik Analisis Data. Jakarta: Salemba Medika.

Indriati. 2009. Panduan Lengkap Kehamilan, Persalinan dan Perawatan Bayi. Jogyakarta : Diglossia Media.

Mander. 2008. Nyeri Persalinan. Jakarta : EGC.
Notoatmodjo. 2010. Metodologi Penelitian Kesehatan. Jakarta : Rineka Cipta.

Nursalam. 2011. Konsep dan Penerapan Metodologi Penelitian Ilmu Keperawatan, Edisi II. Jakarta. Salemba Medika.

Potter, 2005. Buku Ajar Fundamental Keperawatan : Konsep, Proses, dan Praktik Jakarta : EGC.

Patree., Walsh. 2007. Buku Ajar Kebidanan Komunitas. Jakarta : EGC.

Prawirohardjo. 2007. Ilmu Kebidanan. Jakarta: EGC.

Schott, J., Priest, J. (2008). Kelas Antenatal. Jakarta : EGC.

Soenario. 2012. Ambang Batas Nyeri Persalinan. http://www.ilmukesehat an. co.id. Diakses tanggal 22 Januari 2014.

Simkin., Walley.,dan Keppler, 2008. Persalinan. Jakarta: EGC.

Smeltzer \& Bare. 2002. Buku Ajar Keperawatan Medikal Bedah Brunner dan Suddarth (Ed.8, Vol. 1,2), Alih bahasa oleh Agung Waluyo...(dkk), Jakarta: EGC.

Suddarth., Brunner. 2008. Buku Ajar Keperawatan MedikalBedah. Jakarta: EGC.

Sugiyono. 2010. Statistika Nonparametris.

Bandung : Alvabeta.

Suryainsaf. 2012. Intensitas nyeri persalinan dan relaksasi pernapasan. http:// www.jiptummpp-gdl- 
s1-2007-suryainsaf-

9064. Diakses tanggal

22 Januari 2014.

Tamsuri, A.2007. Konsep dan penatalaksanaan nyeri. Jakarta : EGC.

Ujiningtyas. $2009 . \quad$ Asuhan

Keperawatan

Persalinan Normal.

Salemba Medika.

Jakarta.

Whalley, Simpkin.,\& Keppler. 2008.

Panduan Praktis Bagi

Calon Ibu : Kehamilan

dan Persalinan. Jakarta

: PT. Bhuana Ilmu

Populer.

Yanti. 2010. Buku Ajar Kebidanan Persalinan. Yogyakarta

: Pustaka Rihama.

Yuliatun. 2008. Penangangan Nyeri

Persalinan Dengan

Metode

Nonfarmakologi.

Malang : Bayumedia

Publishing. 